Biol Neonate 44:219

13. Gabriel M, Hunneman DN, Gahr M 1983 Plasma levels of catecholamine metabolites in the newborn period. Biol Neonate 44:203

14. Hahn Z 1980 Centrifugal microfiltration: A simple way to enhance the sensitivity of the classical aluminium oxide adsorption method of fluorimetric catecholamine determination. J Biochem Biophys Methods 2:163

15. Haning R, Tait SAS, Tait JF 1970 In vitro effects of ACTH, angiotensins, serotonin and potassium on steroid output and conversion of corticosterone to aldosterone by isolated adrenal cells. Endocrinology 87:1147

16. Honour JW, Valman HB, Shackleton CHL 1977 Aldosterone and sodium homeostasis in preterm infants. Acta Paediat Scand 66:103

17. Koketsu K, Shirasawa Y 1974 5-HT and the electrogenic sodium pump. Experientia 30:1034

18. Nakai T, Yamada R 1978 The secretion of catecholamine in the newborn babies with special reference to fetal distress. J Perinatal Med 6:39

19. Nakai T, Yamada R 1983 Urinary catecholamine excretion by various age groups with special reference to clinical value of measuring catecholamines in newborns. Pediatr Res 17:456

20. Nicolopoulos D, Agathopoulos A, Danelatou-Athanassiadou C, Bafataki M 1968 Urinary excretion of phenolic and indolic compounds, metacatecholamines and VMA by full-term and premature infants. Pediatrics 41:777

21. Nicolopoulos D, Agathopoulos A, Galanakos-Tharouniati M, Stergiopoulos C 1969 Urinary excretion of catecholamines by full-term and premature infants. Pediatrics $44: 262$

22. Oliver JA, Pinto J, Sciacca RR, Cannin PJ 1980 Increased renal secretion of norepinephrine and prostaglandin $E_{2}$ during sodium depletion in the dog. $J$ Clin Invest 66:748

23. Page IH 1958 Serotonin/5-hydroxytryptamine: the last four years. Physiol Rev $38: 277$

24. Pelayo JC, Jose PA 1982 The influence of age on the renal effects of dopamine. Pediatr Res 16:12917 (abstr)

25. Romoff MS, Keusch G, Campese VM, Wang MS, Friedler RM, Weidmann P Massry SG 1979 Effect of sodium intake on plasma catecholamines in normal subjects. J Clin Endocrinol Metab 48:26
26. Ross B, Cowett RM, Oh W 1977 Renal functions of low birth weight infants during the first two months of life. Pediatr Res 11:1162

27. Roy RN, Chance GW, Radde IC, Hill HE, Willis DM, Sheepers J 1976 Late hyponatraemia in low birth weight $(<1.3 \mathrm{~kg})$ infants. Pediatr Res 10:526

28. Schiff D, Stern L, Leduc J 1966 Chemical thermogenesis in newborn infants: catecholamine excretion and the plasma non-esterified fatty acid response to cold exposure. Pediatrics $37: 577$

29. Slick GL, Aquilera AJ, Zambraski EJ, DiBona GF, Kaloyanides GJ 1975 Renal neuroadrenergic transmission. Am J Physiol 229:60

30. Stern L, Lees MM, Leduc J 1965 Environmental temperature, oxygen consumption and catecholamine excretion in newborn infants. Pediatrics $36: 367$

31. Sulyok E 1971 The relationship between electrolyte and acid-base balance in the premature infant during early postnatal life. Biol Neonate 17:227

32. Sulyok E, Német M, Tényi I, Csaba IF, Györy E, Ertl T, Varga F 1979 Postnatal development of renin-angiotensin-aldosterone system, RAAS, in relation to electrolyte balance in premature infants. Pediatr Res 13:817

33. Sulyok E, Varga F, Györy E, Jobst K, Csaba IF 1979 Postnatal development of renal sodium handling in premature infants. J Pediatr 95:787

34. Sulyok E, Németh M, Tényi I, Csaba IF, Varga L, Varga F 1982 Relationship between the postnatal development of the renin-angiotensin-aldosterone system and electrolyte and acid-base status of the $\mathrm{NaCl}$ supplemented premature infants. In: Spitzer A (ed) The Kidney during Development. Morphology and Function. Masson, New York, p 273

35. Tulassay T, Seri I, Machay T, Kiszel J, Varga J, Csömör S 1983 Effects of dopamine on renal functions in premature neonates with respiratory distress syndrome. Int J Pediatr Nephrol 4:19

36. Voorhess ML 1967 Urinary catecholamine excretion by healthy children. I. Daily excretion of dopamine, norepinephrine, epinephrine and 3-methoxy4-hydroxymandeleic acid. Pediatrics 39:252

37. Zimmerman BG 1978 Actions of angiotensin on adrenergic nerve endings. Fed Proc 37:199

38. Zimmermann H, Ganong WF 1980 Pharmacological evidence that stimulation of central serotonergic pathways increases renin secretion. Neuroendocrinology 30:101

\title{
Radioimmunoassay for Type I Procollagen in Growth Hormone-deficient Children before and during Treatment with Growth Hormone
}

\author{
DENNIS E. CAREY, BURTON GOLDBERG, SUSAN K. RATZAN, KAREN R. RUBIN, AND \\ DAVID W. ROWE
}

\begin{abstract}
Department of Pediatrics, Newington Children's Hospital, Newington, Connecticut 06111 and the University of Connecticut Health Center, Farmington, Connecticut 06032 [D.E.C., S.K.R., K.R.R., D.W.R.] and Department of Pathology, New York University, Medical Center, New York, New York 10016 [B.G.]
\end{abstract}

\begin{abstract}
Type I procollagen concentrations were measured by radioimmunoassay in sera from 14 growth hormone-deficient children before and during 12 months of treatment with human growth hormone. Basal procollagen levels were lower than those of control children and comparable to those of normal adults. With treatment, the mean procollagen level increased into the range of the control children and was significantly greater than the baseline level at $1,2,3^{*}$, and 12 months $\left(p<0.01\right.$; ${ }^{*} p<$ 0.05). Although there was no significant statistical corre-
\end{abstract}

Received January 6, 1984; accepted June 13, 1984

Requests for reprints should be addressed to Dennis E. Carey, M.D., Newington Children's Hospital, 181 E. Cedar Street, Newington, CT 06111.

This research was supported in part by National Institutes of Health Grant HL17551 and by an award of human growth hormone by the National Hormone and Pituitary Program. lation between the growth velocity during treatment and the serum procollagen level, there was a suggestion that a high basal procollagen may be predictive of a less than optimal response to human growth hormone. (Pediatr Res 19: 8-11, 1984)

\section{Abbreviations}

RIA, radioimmunoassay

hGH, human growth hormone

ANOVA, analysis of variance

Somatic growth results from the generation of new supporting and connective tissues. Since collagen is the major protein con- 
stituent of connective tissue, its synthesis must be a prerequisite for normal growth. A RIA for human type I procollagen showed that sera from newborn cord blood had about 12-fold higher concentrations of the antigen than those in adult sera (1). This finding is presumed to reflect the greater degree of collagen synthesis in rapidly growing newborns as compared to fully grown adults. The serum procollagen level, by virtue of its intermediate position between growth promoting hormones and growth itself, might, therefore, have clinical usefulness as a nonspecific biochemical marker of the response to growth stimuli. In order to evaluate the relationship between the serum procollagen and growth, we studied procollagen levels in 14 growth hormone-deficient children prior to and during replacement therapy with hGH.

\section{MATERIALS AND METHODS}

Subjects. Written, informed consent was obtained from the parents of the subjects. Clinical data on the 14 children with growth hormone deficiency who participated in the study are summarized in Table 1. The diagnosis of growth hormone deficiency was made by demonstrating failure of the serum growth hormone concentration to rise to at least $7 \mathrm{ng} / \mathrm{ml}$ after administration of two of the following: insulin-induced $(0.1 \mathrm{unit} / \mathrm{kg})$ hypoglycemia; arginine infusion $(0.5 \mathrm{~g} / \mathrm{kg})$; or L-dopa $(500 \mathrm{mg})$ (2). Eleven children had idiopathic growth hormone deficiency. The remaining three had organic hypopituitarism and had undergone both neurosurgery and cranial irradiation. Children with multiple hormone deficiencies were given appropriate replacement therapy prior to the initiation of the study. The patients were prepubertal except for one girl with Tanner II pubic hair. All of the girls had 46XX karyotypes.

Experimental protocol. Basal control samples were obtained from 52 normally growing children being evaluated for short stature in the Growth Disorders Clinic at the Newington Children's Hospital. All control children had a skeletal age between 2 and 13 years, were well nourished, and had a diagnosis of either familial short stature, constitutional delay of maturation, or a combination. Native hGH was supplied by the National Hor-

Table 1. Clinical data on children with growth hormone deficiency*

\begin{tabular}{|c|c|c|c|c|}
\hline Patient & Sex & $\begin{array}{l}\text { Age } \\
\text { (years) }\end{array}$ & $\begin{array}{c}\text { Bone age } \\
\text { (years) }\end{array}$ & Comments \\
\hline A. A. & $\mathrm{F}$ & $3-0 / 12$ & $6 / 12$ & $\begin{array}{l}\text { TSH/ACTH deficient on } \mathrm{T}_{4} \\
\text { and cortisol; IGR and dys- } \\
\text { morphic }\end{array}$ \\
\hline M. B. & $\mathrm{F}$ & $11-1 / 12$ & $7-10 / 12$ & \\
\hline M. V. & $M$ & $6-0 / 12$ & $3-9 / 12$ & \\
\hline S. $\mathrm{C}_{1}$ & M & $7-5 / 12$ & $3-5 / 12$ & \\
\hline C. R. & $\mathrm{F}$ & $13-0 / 12$ & $10-0 / 12$ & Tanner II pubic hair \\
\hline N. R. & $\mathrm{M}$ & $7-1 / 12$ & $7-0 / 12$ & $\begin{array}{l}\text { Ependymoma of } 4 \text { th ventri- } \\
\text { cle }\end{array}$ \\
\hline J. $\mathrm{H}_{1}$ & $\mathrm{M}$ & $11-8 / 12$ & $7-6 / 12$ & $\begin{array}{l}\text { Craniopharyngioma; pan- } \\
\text { hypopituitarism with DI } \\
\text { on replacement }\end{array}$ \\
\hline C. G. & $\mathrm{F}$ & $5-7 / 12$ & $3-6 / 12$ & $\mathrm{TSH}$ deficient on $\mathrm{T}_{4}$ \\
\hline A. G. & M & $10-5 / 12$ & & $\begin{array}{l}\text { Craniopharyngioma; pan- } \\
\text { hypopituitarism with DI } \\
\text { on replacement }\end{array}$ \\
\hline S. $\mathrm{C}_{2}$ & M & $9-8 / 12$ & $6-0 / 12$ & \\
\hline R. P. & M & $9-4 / 12$ & $6-6 / 12$ & \\
\hline J. $\mathrm{H}_{2}$ & M & $7-5 / 12$ & $5-0 / 12$ & \\
\hline D. W. & $\mathrm{F}$ & $12-5 / 12$ & $8-5 / 12$ & TSH deficient $\mathrm{T}_{4}$ \\
\hline T. B. & M & $15-8 / 12$ & $13-3 / 12$ & $\begin{array}{l}\text { Gonadotropin deficiency- } \\
\text { not replaced }\end{array}$ \\
\hline
\end{tabular}

* TSH, thyroid stimulating hormone; ACTH, adrenocorticotropic hormone; IGR, intrauterine growth retardation; DI, diabetes insipidus; $\mathrm{T}_{\mathbf{4}}$, thyroxine. mone and Pituitary Program. Treatment consisted of intramuscular injections of hGH three times per wk in a dose of $0.1 \mathrm{IU} /$ $\mathrm{kg}$. Serum for determination of immunoreactive procollagen was obtained prior to the initiation of therapy and at $1 \mathrm{wk}$ and 1,2 , 3,6 , and 12 months during treatment. All seven determinations were completed in 8 of 14 subjects.

Procollagen assay. The RIA for human type I procollagen was performed essentially as reported $(1,3,4)$. The source of the antigen was type I procollagen precipitated from the medium of cultured human diploid fibroblasts. The triple-helical portion of the procollagen molecule was digested with bacterial collagenase and the collagenase-resistant carboxy terminal propeptide fragment was then recovered by DEAE-cellulose ion exchange chromatography $(5,6)$. The isolated fragment, a disulfide-linked three-chain molecule of 100,000 daltons was used as the antigen. Rabbits were immunized with the antigen by conventional procedures. The serum IgG was then isolated and purified by affinity chromatography.

The antigen $(25 \mu \mathrm{g})$ was labeled with ${ }^{125} \mathrm{I}$ by the chloramine-T method (7). Antisera and IgG were titered against the radiolabeled antigen, and an $\mathrm{IgG}$ concentration $(\sim 3 \mathrm{ng})$ that bound $50 \%$ of the input radioactivity $(100,000 \mathrm{cpm})$ was used in each tube of the RIA. Assay tubes containing dilutions of standard unlabeled antigen or dilutions of unknown sera were prepared in triplicate. All tubes contained carrier normal rabbit serum; control tubes omitted unlabeled antigen, and unlabeled antigen and antibody, respectively. After the antibody additions, the tubes were incubated for $2 \mathrm{~h}$ at $37^{\circ} \mathrm{C}$. The radiolabeled antigen $(100,000 \mathrm{cpm} /$ tube $)$ was then added and the tubes were incubated for $1 \mathrm{~h}$ at $37^{\circ} \mathrm{C}$, and then for $18 \mathrm{~h}$ at $4^{\circ} \mathrm{C}$. Bound antigen was precipitated with sheep anti-rabbit IgG antiserum and the centrifuged pellets were counted in a gamma spectrometer.

Figure 1 shows typical curves generated by additions of unlabeled procollagen antigen and dilutions of subject serum. The serum dilutions produced parallel displacement of label relative to standard antigen. Sera were diluted so that displacements were measured in the $20-70 \%$ range and antigen concentrations were read from the standard curve. The coefficients of variation (standard deviation $\times 100 /$ mean) were 3.6 and 7.8 for within assay, and between assay measurements, respectively.

Statistical analysis (8). ANOVA for repeated measures was used to assess the effect of time as a variable. Cases D.W. and T.B. were excluded from the ANOVA (missing baseline values) and data for eight empty cells were estimated using the Yates method. Comparison of each time with baseline was done using Tukey's honestly significant difference method for multiple com-

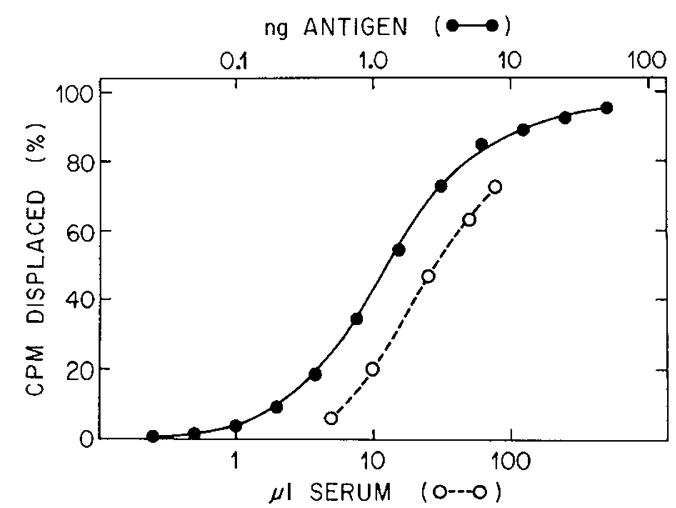

Fig. 1. Procollagen radioimmunoassay: competitive displacement by reference antigen and a subject serum. Increasing amounts of unlabeled propeptide antigen (solid line) or serum $(12.5 \times$ dilution, dashed line) were incubated with antibody followed by incubation with radioiodinated propeptide antigen. Immune complexes were precipitated with sheep anti-rabbit IgG and the radioactivity in the pellets was measured. The curves were fitted visually through average data points. Illustrated subject serum contains $57 \mu \mathrm{g} / \mathrm{dl}$, by calculation from the standard curves. 
parisons. The relationship of treated growth velocity to basal, peak, and incremental serum procollagen levels was analyzed using Pearson's $R$ coefficient.

\section{RESULTS}

The mean $( \pm \mathrm{SE})$ serum procollagen concentrations in the basal state and during hGH therapy are shown in Figure 2. The mean procollagen concentration in untreated growth hormone-deficient children of $11.9 \pm 2.0 \mu \mathrm{g} / \mathrm{dl}$ was significantly less than that of the child controls of $31.9 \pm 1.3 \mu \mathrm{g} / \mathrm{dl}(p<0.001)$ and within the adult range $(2-14 \mu \mathrm{g} / \mathrm{dl})$. The mean value increased to 16.5 $\mu \mathrm{g} / \mathrm{dl}$ at the end of the 1 st wk of therapy and to $22.9 \mu \mathrm{g} / \mathrm{dl}$ at the end of 1 month. Thereafter, the mean procollagen level remained greater than the baseline with values of $22.9 \mu \mathrm{g} / \mathrm{dl}$ at 2 months, $21.6 \mu \mathrm{g} / \mathrm{dl}$ at 3 months, $19.0 \mu \mathrm{g} / \mathrm{dl}$ at 6 months, and $23.6 \mu \mathrm{g} / \mathrm{dl}$ at 1 year. ANOVA appropriate for repeated measures designs showed a significant effect of the time variable $(F=5.07, p<$ 0.01 ). Differences from baseline became significant at 1 month and remained significant at 2,3 , and 12 months. The mean values at $1,2,3$, and 12 months were within the lower portion of the range for child controls $(19.5$ to $59 \mu \mathrm{g} / \mathrm{dl})$. The mean value at 6 months was $60 \%$ above the baseline. However, it was just below the range for child controls and not significantly different from the baseline. The procollagen level more than doubled in 10 of the 12 growth hormone-deficient children for whom both basal and peak values were available (Fig. 3). The mean peak procollagen level was $29.2 \pm 2.9 \mu \mathrm{g} / \mathrm{dl}$. This value was not significantly different than the mean level in control children. One child had no increment in procollagen. Procollagen levels in the two children in whom basal values were not available (open circles, Fig. 3) were similar to the mean value for the 12 children after treatment.

There was no significant correlation between treated growth velocity and either basal $(r=-0.060)$, peak $(r=-0.148)$, or incremental ( $r=-0.125)$ serum procollagen levels. Table 2 lists the growth velocity during therapy as well as the basal procollagen levels.

\section{DISCUSSION}

Collagen is synthesized in a precursor form, procollagen, distinguished by the presence of extension propeptides at the ends of the helical collagen $\alpha$ chains. The propeptides are subject to excision in the course of secretion and formation of extracellular collagen fibrils. Our RIA is specific for the carboxy terminal

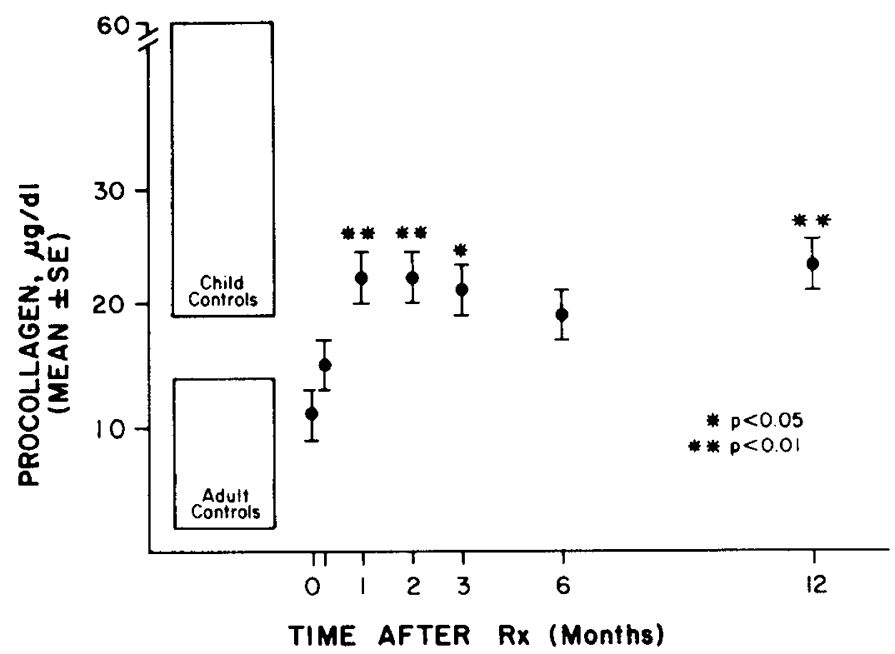

Fig. 2. Serum procollagen levels in control children, adults, and growth hormone-deficient children before and during 1 year of hGH treatment. Control bars show the mean $\pm 2 \mathrm{SD}$ range of values. Results in hGH-deficient children are shown as mean $\pm \mathrm{SE}$.

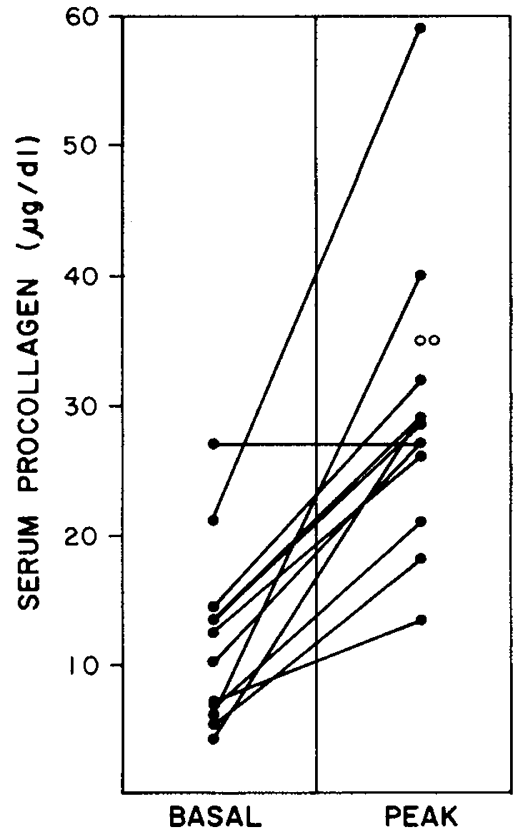

Fig. 3. Basal and peak serum procollagen concentrations in the hGHtreated children. Basal and peak values were available for 10 of the 12 children. The open circles show the peak levels in the two treated children whose basal values were not available.

Table 2. Comparison of individual basal procollagen levels to growth velocity during hGH therapy

\begin{tabular}{ccc}
\hline Subject & $\begin{array}{c}\text { Post-hGH } \\
\text { growth rate } \\
(\mathrm{cm} / \text { year })\end{array}$ & $\begin{array}{c}\text { Basal procollagen } \\
(\mu \mathrm{g} / \mathrm{dl})\end{array}$ \\
\hline A. A. & 3.0 & 12.6 \\
M. B. & 4.9 & 14.5 \\
M. V. & 5.8 & 13.5 \\
S. C 1 & 6.4 & 21.2 \\
C. R. & 7.6 & 5.6 \\
N. R. & 8.0 & 4.2 \\
J. H & 8.9 & 7.2 \\
C. G. & 8.9 & 13.6 \\
A. G. & 9.1 & 7.0 \\
S. C 2 & 10.3 & 6.3 \\
R. P. & 10.8 & 10.2 \\
J. H $_{2}$ & 10.8 & 27.0 \\
\hline
\end{tabular}

propeptides of human type I procollagen, as they exist in the intact precursor molecule, or after they are physiologically excised as a disulfide-linked, three-chain fragment of 100,000 daltons. Current evidence favors the view that the carboxy terminal propeptide fragment is excised before the procollagen is incorporated into fibrils in the extracellular space $(9,10)$. The concentration of the propeptide in serum should reflect recently synthesized collagen rather than resorption of previously formed collagen fibrils. Measurements of serum procollagen levels, therefore, do not evaluate the same aspects of collagen metabolism as the measurement of urinary hydroxyproline. The latter reflects both synthesis and turnover of collagen molecules and fibrils of all genetic types, as well as the dietary intake of collagenous proteins (11).

Because type I collagen is the most abundant collagen type and the major matrix protein of bone, we sought a correlation between serum procollagen values and linear growth. For this purpose, we chose to evaluate children treated for growth hormone deficiency. We found the mean pretreatment serum procollagen level of growth hormone-deficient children to be within 
the normal range for adults and significantly lower than levels in short children without growth failure. All but two individual basal procollagen levels were below the range of the child controls and within the range of adult controls. Replacement therapy with exogenous hGH produced a sustained increase in the mean serum procollagen level and 12 of 14 peak levels were within the range of child controls. Overall, the data demonstrate that poor growth is accompanied by low serum procollagen levels similar to those in nongrowing adults and that stimulation of growth with $\mathrm{hGH}$ in growth hormone-deficient children results in an increase in serum procollagen to levels more comparable to that of children with normal growth velocity. The results suggest that type I collagen synthesis is diminished in growth hormonedeficient children and is restored toward normal during therapy which promotes linear growth. Complete restoration may not have been obtained since the mean procollagen levels during therapy remained in the lower portion of the control range.

Decreased collagen synthesis in association with growth failure appears not to be limited to growth hormone deficiency since we have found low basal procollagen levels in poorly growing children with primary hypothyroidism (12) and inflammatory bowel disease (13). The serum procollagen level may, therefore, be a nonspecific biochemical marker of biologic response to growth stimuli.

A biochemical marker for growth would be most useful if it predicted growth within a time frame shorter than that needed for the measurement of linear growth. Because enhanced collagen synthesis is a prerequisite for growth, we speculated that the serum procollagen response to hGH therapy would be predictive of the linear growth response. Statistical analysis revealed, however, that there was no significant correlation between the growth velocity and the basal, incremental, and peak serum procollagen values during treatment with $\mathrm{hGH}$. Other investigators have reported a lack of correlation between linear growth response to $\mathrm{hGH}$ and levels of serum somatomedin-C $(14,15)$ or urinary epidermal growth factor (16).

We observed, with the exception of subject $\mathrm{J} . \mathrm{H}_{2}$, a clustering of higher basal procollagen values in the poorer growth responders (post-hGH growth velocity $<6.5 \mathrm{~cm} /$ year) and the lower values in better responders. Also noteworthy is the observation that three subjects with organic hypopituitarism (N. R., J. $H_{1}$, and A. G.), had very low basal procollagen levels and each had a good growth response to $\mathrm{hGH}$. These data suggest that a "high" basal procollagen level may be predictive of a poor or less than optimal response to hGH.

The lack of statistical correlation between serum procollagen levels and linear growth responses in the present study possibly could be explained by variation in the timing of blood sampling in relation to hGH administration or an unrecognized lack of homogeneity in the growth hormone-deficient population. Strict temporal coupling of sampling to hormone administration and expansion of the study population might clarify this relationship.

Despite the lack of significant correlation between growth velocity and serum procollagen response, the positive change in serum procollagen following $\mathrm{hGH}$ treatment suggests that serum procollagen may be a marker for an anabolic response viz. collagen synthesis and secretion. Further investigations are necessary to establish age-related norms for procollagen and to assess procollagen levels in other disorders associated with growth failure.

Acknowledgment. The authors thank Lorraine Fox for her invaluable secretarial assistance.

\section{REFERENCES}

1. Taubman MB, Goldberg B, Sherr CJ 1974 Radioimmunoassay for human procollagen. Science 186:1115-1117

2. Kaplan SA 1982 Growth and growth hormone: disorders of the anterior pituitary. In: Kaplan SA (ed) Clinical Pediatric and Adolescent Endocrinology. WB Saunders Co, Philadelphia, pp 1-48

3. Taubman MB, Kammerman S, Goldberg B 1976 Radioimmunoassay of procollagen in serum of patients with Paget's disease of bone. Proc Soc Exp Biol Med 152:284-287

4. Taubman MB, Goldberg B 1978 Antigenic relatedness of primate procollagen as determined by a competitive radioimmunoassay. Comp Biochem Physiol 59:47-49

5. Sherr CJ, Taubman MB, Goldberg B 1973 Isolation of a disulfide-stabilized, three-chain polypeptide fragment unique to the precursor of human collagen. J Biol Chem 248:7033-7038

6. Olsen BR, Guzman NA, Engel J, Condit C, Steinar A 1977 Purification and characterization of a peptide from the carboxyterminal region of chick tendon procollagen type I. Biochemistry 16:3030-3036

7. Greenwood FC, Hunter WM, Glover JS 1963 The preparation of ${ }^{131}$ I-labeled human growth hormone of high specific radioactivity. Biochem J 89:114123

8. Winer BJ 1971 Statistical Principles in Experimental Design, 2nd ed. McGrawHill, New York

9. Fleischmajer R, Timpl R, Tuderman L, Raisher L, Wiestner M, Perlish JS, Graves PN 1981 Ultrastructural identification of extension amino-propeptides of type I and III collagens in human skin. Proc Natl Acad Sci USA 78:7360-7364

10. Fleischmajer R, Olsen BR, Timpl R, Perlish JS, Lovelace O 1983 Collagen fibril formation during embryogenesis. Proc Natl Acad Sci USA 80:33543358

11. Krane SM, Munoz AJ, Harris ED Jr 1967 Collagen-like fragments: excretion in urine of patients with Paget's disease of bone. Science 157:713-715

12. Carey DE, Goldberg B, Ratzan SK, Rubin K, Rowe DW 1982 Serum immunoreactive procollagen levels in children with growth hormone deficiency and hypothyroidism. Pediatr Res 16:135A (abstr)

13. Rosenfeld RG, Kemp SF, Hintz RL 1981 Constancy of somatomedin response to growth hormone treatment of hypopituitary dwarfism and lack of correlation with growth rate. J Clin Endocrinol Metab 53:611-617

14. Van Vliet GV, Styne DM, Kaplan SL, Grumbach MM 1983 Growth hormone treatment for short stature. N Engl J Med 309:1016-1022

16. Levitsky LL, Edidin DV, Benveniste R 1982 Urinary excretion of epidermal growth factor (EGF) in growth hormone deficient children before and after treatment with growth hormone. Pediatr Res 16:140A (abstr) 